Resolved by the Senate and House of Representatives of the United States of America in Congress assembled, That the notice thus given by the President of the United States to the Government of the Empire of Russia to terminate said treaty in accordance with the terms of the Treaty is hereby adopted and ratified.

It will be observed that the resolution makes no mention of the political principles held by the United States, and omits the charge that Russia has violated the treaty. The substitute resolution was concurred in by the House on December 20th and approved by the President on December 21st.

\title{
THE INTERNATIONAL JOINT COMMISSION BETWEEN THE UNITED STATES AND CANADA
}

On January 11, 1909, a treaty was signed between Great Britain and the United States concerning the boundary waters between the United States and Canada, the ratifications of which were exchanged on May 5, 1910. The treaty had a threefold purpose: first, to prevent disputes regarding the use of boundary waters; second, "to settle all qestions which are now pending between the United States and the Dominion of Canada, involving the rights, obligations, or interests of either in relation to the other or to the inhabitants of the other, along their common frontier"; and third, "to make provision for the adjustment and settlement of all such questions as may hereafter arise." It would therefore appear that the existence of disputes regarding the use of boundary waters gave the opportunity, which was eagerly seized, to agree to settle all pending questions, whatever their nature; and at the same time, in order that the friendly relations between Canada and the United States should not be disturbed, Great Britain and the United States agreed to make a provision for the adjustment and settlement of future disputes. It is not the purpose of the present comment to analyze in detail this important treaty, as it has been the subject of an extended comment in a previous issue of the Journal. ${ }^{1}$ It is intended merely to call attention to the method by which the three classes of disputes are to be settled peaceably and the steps taken to make the method effective.

By Article VII of the treaty Great Britain and the United States agree to establish a permanent International Joint Commission.

1 See Editorial Comment in the July, 1910, number, p. 668, and text of the treaty in the Supplement for July, 1910, p. 239. 
Article VIII clothes the commission with jurisdiction of the differences specified in Articles III and IV of the treaty, which are, however, immaterial for the present purpose.

Article IX provides that:

any other questions or matters of difference arising between them involving the rights, obligations, or interests of either in relation to the other or to the inhabitantso of the other, along the common frontier between the United States and the Dominion of Canada, shall be referred from time to time to the International Joint Commission for examination and report, whenever either the Government of the United States or the Government of the Dominion of Canada shall request that such questions or matters of difference be so referred.

It is provided by a subsequent paragraph of the same article that:

such reports of the commission shall not be regarded as decisions of the ques. tions or matters so submitted either on the facts or the law, and shall in no way have the character of an arbitral award.

That is to say, in the differences specified in Articles III and IV of the treaty the commission is to act as a court of law and render judgment, whereas under Article IX the commission shall on the request of either government examine and report on the law and the facts, but their findings shall not be binding either as a decision or as an arbitral award. It is, however, important to note that the contracting parties agree to refer questions from time to time and that an obligation to do so is created by express language, for in such cases the word " shall" is construed as mandatory. Were the commission limited to these important categories it would be able to render signal service to the cause of international peace and good understanding; but the tribunal is invested with a greater usefulness by Article X, although a moral, rather than a legal, obligation is created because the contracting parties do not bind themselves absolutely to refer future differences but state that they "may be referred." The text of this important article is as follows:

Any questions or matters of difference arising between the high contracting parties involving the rights, obligations, or interests of the United States or of the Dominion of Canada either in relation to each other or to their respective inhabitants, may be referred for decision to the International Joint Commission by the consent of the two parties, it being understood that on the part of the United States any such action will be by and with the advice and consent of the Senate, and on the part of His Majesty's Government with the consent of the Governor General in Council. In each case so referred, the said commission is authorized to examine into and report upon the facts and circumstances of the particular questions and matters referred, together with such conclusions 
and recommendations as may be appropriate, subject, however, to any restrictions or exceptions which may be imposed with respect thereto by the terms of the reference.

It will be observed that no reservation or qualification of any kind is contemplated, for the article expressly says: "any questions or matters of difference arising between the high contracting parties involving rights, obligations, or interests . . . may be referred." It is intended, however, that the decision reached shall bind the governments, because any reference is to be " by and with the advice and consent of the Senate," for if the commission is unable to agree, the "questions or matters shall thereupon be referred for decision by the high contracting parties to an umpire chosen in accordance with the procedure prescribed in the fourth, fifth, and sixth paragraphs of Article XLV of the Hague Convention for the Pacific Settlement of International Disputes, dated October 18, 190\%." It is further provided in the last clause of this important article that the umpire so chosen "shall have power to render a final decision with respect to these matters and questions so referred on which the commission failed to agree." It is not too much to say that this article constitutes a permanent international tribunal between Canada and the Lnited States to which any questions or matters of difference arising between them may be referred and decided by the principles of law and justice.

The United States appointed as its commissioners the late Senator Thomas H. Carter, the Honorable James A. Tawney, and Mr. Frank Sherwin Streeter, and Great Britain appointed the following Canadians: the Honorable T. Chase Casgrain, the Honorable Henry A. Powell, and the Honorable Charles A. MeGrath. To fill the vacancy caused by the death of Senator Carter, the United States appointed the Honorable George Turner, formerly Senator from Washington, commissioner in the Alaskan boundary dispute, and counsel for the United States in the recent Fisheries Arbitration. The commissioners met at Washington on January 10, 1912, and organized.

The opportunity is afforded the commision to establish beyond peradventure the advantages of a permanent international tribunal in deciding according to law and justice controversies that arise between the United States and the Dominion of Canada, and it is gratifying to learn from the addresses delivered by Mr. Commissioner Tawney on behalf of the Tnited States, and by Mr. Commissioner Casgrain, on behalf of Canada, 
that the importance of the tribunal and the services it may render, if it act under a sense of judicial responsibility, are fully appreciated by the tribunal as a whole. The opening addresses follow in full.

\section{Address of Mr. Commissioner Tawney.}

We are met to organize the International Joint Commission authorized by the treaty between the United States and Great Britain, signed January 11, 1909, and proclaimed May 13, 1910.

Personally, and on behalf of my colleagues, I express the belief that upon the interpretation of the powers and duties of this commission and the ability of its members to disassociate themselves in its service on this commission from their individual relations to their respective governments, depends the success or failure of this international effort to create a judicial tribunal, broader than our respective nationalities and almost continental in its jurisdiction, for the adjudication of differences that now exist or that may hereafter arise along our common frontier.

On Christmas eve, 1814, there was concluded and signed in the old cathedral at Ghent a treaty which began with this significant and important declaration: "There shall be a firm and universal peace between His Britannic Majesty and the United States and between their respective countries, territories, cities, towns and people of every degree without exception of places or persons." That declaration was comprehensive and so attuned to the Christmas spirit of universal peace that pessimists criticized the negotiators for the use of sentimental rather than practical expressions in treaty making. Since then all misunderstandings and controversies between these two nations have been settled by an appeal to reason rather than to passion. The Treaty of Ghent has been sacredly observed for 98 years, during which time every misunderstanding between Great Britain and the United States has been settled either through established drplomatic agencies or by a temporary commission composed of the representatives of both nations. Notwithstanding this fact, in our judgment this International Joint Commission is the most promising agency that has yet been created for the settlement of controversies between these two nations; because it brings together, face to face, representatives of Canada and the United States to impartially consider and adjudicate the questions that now exist or that may develop along our international boundaries which stretch nearly four thousand miles across the continent, where two great peoples are living as neighbors but under two national jurisdictions.

Plans have been inaugurated in the United States, in Canada and in England to celebrate the centennial of the Treaty of Ghent on both sides of the boundary and on both sides of the Atlantic. Such a movement can only result in a profound sentiment for international peace, and we can conceive of no greater contribution to its success than the calm, judicious effort of the members of this commission to carry into effect the newer treaty of January 11, 1909. The Treaty. of Ghent at the beginning of the nineteenth century opened the way to inquiry as to where should be the exact international boundary, and it was followed by an agreement to dismantle all forts and warships along that boundary. The treaty of 1910 begins the twentieth century with a commission to which may 
be referred for inquiry and adjudication all possible questions of disagreement between the Dominion of Canada and the United States, their provinces and states and their respective peoples. This is an effort to write into international law the sentiment of the peoples of two great countries. We have, therefore, a powerful incentive to carry forward this work of a century, in which the emblems of force have given way to the symbols of peaceful agencies for the judicial settlement of all possible international controversies which the established peaceful agencies for that purpose of the two governments may be unable to determine.

The work of promoting closer and more direct relations between the two great peoples on this continent who have the same language, come from the same race, have the same common fountain of law, the same traditions, and similar institutions of government as well as the same ambitions for the continued success of their respective governments, is in fact the work of blazing the trail for the judicial settlement of all disputes where they occur between any two great nations. This is a work that any man may well appreciate the honor of having been selected to engage in.

The chief cause for congratulation, however, is that this treaty has provided a means for frank, direct and constant relations between the two great neighboring peoples who inhabit the greater part of the North American cortinent, and who must live in amicable relations to realize the ultimate ideal of our Anglo-Saxon civilization. This commission constitutes the medium for this direct communication, and to it, by the express terms of the treaty, may be referred for consideration and settlement all questions of difference that may arise between the peoples living along our common frontier. Although the treaty was signed January 11, 1909, it expressly authorizes and clothes this commission with jurisdiction to consider and determine all questions of difference, without reservations or qualifications of any kind. As a distinguished Canadian jurist, Mr. Justice Reddell of the King's Bench of Ontario, has well said: "This may be called a miniature Hague Tribunal of our own; just for us English-speaking nations of the continent of North America."

I am not idealist enough to assume that any of us can wholly divest himself of national sentiment to here assure the world that he has reached that state of human perfection that constitutes the absolutely impartial judge in international affairs; but $I$ believe we all realize our obligation to fairly and fully examine every question that may be presented and try to reach a judicial settlement that will contribute to the better understanding and bear out the spirit of the treaty, which is an agreement in part for the joint regulation of common property of great value to the peoples on both sides of the international boundary. I do not understand that we are the agents of separate governments to meet and bicker over contested questions, but rather the joint representatives of the two governments to cooperate in the examination and judicial settlement of questions that are of mutual interest.

As members of this commission we are, therefore, neither Canadians nor Americans, but we are each and all representatives of all the people on both sides of our international boundary line. We can have before us no disputes or disagreements about where this boundary is, and in so far the employment of the terms "Boundary Treaty" or "Waterways Treaty" is misleading. We 
are to consider the uses, diversions, and obstructions of the boundary waters as a primary duty and also adjudicate any and all other questions of difference or disagreement between the peoples of the United States and Canada as may from time to time be referred to the commission by the mutual action and consent of the two governments. It is, therefore, no insignificant or mere temporary and incidental work we face in the organization of this commission. We have a great responsibility resting upon us to shape our work so as to vitalize the international powers conferred by the treaty, realize the hopes and aspirations of the two peoples here living under law, and the destinies of two nations that now dominate the richest land on the globe.

I hope that whatever else we may accomplish we shall demonstrate the wisdom of Great Britain in clothing the Dominion of Canada with responsibility of conducting her own foreign relations with the United States that fall under the jurisdiction of this treaty through the medium of this commission, and that the present neighborly feeling will be strengthened by the manner in which we consider and determine the questions that will be presented.

I hope also that the spirit of our judgments will be in conformity with the principles announced by the great English judge, Lord Stowell, whose decisions are equally admired, respected, and followed in both countries, and that we may adopt the measured language of Christopher Gore, like ourselves a member of a commission to decide peacefully international disputes between Great Britain and the United States. In delivering judgment in the prize case entitled The Maria (1 C. Robinson, 340), decided in 1799, Lord Stowell, then Sir William Scott, said:

"In forming that judgment I trust that it has not escaped my anxious recollection for one moment what it is that the duty of my station calls for from me - namely, to consider myself as stationed here, not to deliver occasional and shifting opinions to serve present purposes of particular national interest, but to administer with indifference that justice which the law of nations holds out without distinction to independent States. The seat of judicial authority is, indeed, locally here, according to the known law and practice of nations, but the law itself has no locality. It is the duty of the person who sits here to determine this question exactly as he would determine the same question as if sitting at Stockholm; to assert no pretensions on the part of Great Britain which he would not allow Sweden in the same circumstances, and to impose no duties on Sweden which he would not admit to belong to Great Britain in the same character. If, therefore, I mistake the law in this matter, I mistake that which I consider, and which I mean should be considered as the universal law upon the question."

And in deciding a case arising under the Jay Treaty, for the settlement of questions growing out of the War of the Revolution - a treaty which laid broad and deep the foundations of modern international arbitration-Mr. Commissioner Gore said:

"Although I am a citizen of but one nation I am constituted a judge for both. Each nation has the same, and no greater right, to demand of me fidelity and diligence in the examination, exactness, and justice of the decision." 


\section{Address of Mr. Commissioner Casgrain.}

The Canadian members of the International Joint Commission desire to express their warm appreciation of the frank and clear statement submitted by the chairman of his views as to the character and scope of the work entrusted to the commission, and they most cordially join in the expression of those sentiments of international good will that exist, and which they feel sure will continue to exist, between the British people and the people of the United States.

We concur with the chairman in the belief that the appointing and bringing together of this commission will go far to settle amicably between two neighbors questions which might otherwise become embarrassing.

We feel sure that working in conjunction with gentlemen who have distinguished themselves in the service of their country, and who are known not only for their profound knowledge of public affairs, but also for the broad spirit with which they approach matters of importance, we will be able to contribute our share towards maintaining that "firm and universal peace between His Britannic Majesty and the United States" of which the Treaty of Ghent speaks.

We are fully alive to the honor and responsibility of the position to which we have been appointed by His Majesty, the King. We are citizens of an integral part of the British Empire, one of the Dominions beyond the Seas, and by the very nature of things, living on this continent and being in constant communication with our good neighbors, the citizens of the United States, we are in a position to see with our own eyes and judge with our own minds what is to the best advantage of the empire we represent For this reason, His Majesty's government, which is ever solicitous of giving to British subjects, in whatever part of the empire they may be, and whatever may be their race, creed or color, the greatest measure of liberty and autonomy, has delegated three of His Majesty's Canadian subjects to meet the delegates of your great republic, and to deal in a fair, impartial and judicial spirit with the important questions mentioned in the treaty.

The people of Canada are largely composed of two races, the French and the English, with different languages and to a large extent different systems of law, but they are firmly united in their adherence to the Crown, and with the rest of the empire they desire that the most amicable relations should forever exist between the high contracting parties whose interests we jointly represent.

SIXTH ANNUAL MEETING OF THE AMERICAN SOCIETY OF INTERNA'TIONAL LAW.

The American Society of Interntaional Law will hold its sixth annua? meeting at Washington, April 25-27, 1912, and the entire session will be devoted to consideration of the questions which might properly enter into the program of a Third Hague Conference and the proper organization which the Conference itself should receive. The subject is of very great international importance and is timely, for although the exact date 